\author{
EISSN:2706-7920 ISSN: 2077-4435 \\ DOI: $10.36632 / \mathrm{csi} / 2021.10 .2 .29$ \\ Journal homepage: www.curresweb.com \\ Pages: 318-323
}

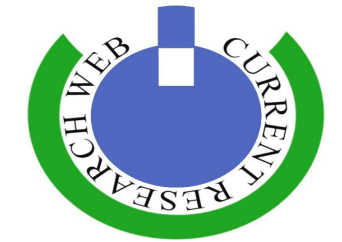

\title{
Radio Utilization for Teaching at Secondary School Level in Owerri Education Zone 1 of Imo State, Nigeria
}

\author{
${ }^{1}$ Mgbam, A.F., ${ }^{2}$ Ezekoka, G.K. and ${ }^{3}$ Okoroma, E.O.
}

\author{
${ }^{1}$ Secondary Education Management Board, Ministry of Education Imo State, Nigeria \\ ${ }^{2}$ Department of Education Technology, Imo State University Owerri, Imo State, Nigeria \\ ${ }^{3}$ Department of Agricultural Extension, University of Uyo, Uyo, Akwa Ibomi State, Nigeria
}

\author{
Received: 06 June 2021 Accepted: 20 June $2021 \quad$ Published: 30 June 2021
}

\begin{abstract}
The advent of Covid-19 pandemic has increased the use of virtual learning channels like the radio at different levels of education in Nigeria. At Secondary School level the development is increasingly becoming thereby eliciting answers as to whether the use of radio for teaching has delivered on the intended purpose. Hence, the purpose of this study was to assess the utilization of radio for teaching at secondary school level in owerri education zone 1 of Imo State, Nigeria. Specifically, the study ascertained ways radio is been utilized in teaching and learning at Secondary school level; assessed the benefits in the use of radio for teaching and learning at Secondary school level; determined factors hindering effective use of radio for education development in Secondary Schools. Data were obtained from 130 teacher respondents sampled through multistage sampling techniques using structured questionnaire. The result indicated that, the sampled teachers acknowledged that radio as mostly used for teaching and learning in distance learning programme $(\bar{X}=2.6)$ as well as creating awareness of topical issues among their students $(\bar{X}=2.7)$. in terms of benefits of using radio, the teachers perceived radio beneficial in stimulating and holding students' interest in learning $(\bar{X}=3.1)$, reaching out to a large number of students at once while teaching $(\bar{X}=2.9)$, eliciting students' active participation when radio is used $(\bar{X}=2.9)$. On constraining factors to the use of radio for teaching, the result revealed that inadequate funding of radio resources $(\bar{X}=3.2)$, limited time allocated for radio programme $(\bar{X}=3.0)$, education planners give little attention in the use of radio $(\bar{X}=3.2)$, lack of educational resource centre in schools $(\bar{X}=3.2)$, were identified by the teachers as factors that constrain their use of radio for teaching at Secondary School level. The study concludes that though the use of radio has huge potentials in enhancing teaching and learning, it is yet to be effectively deployed for teaching at Secondary School level in the study area. It is recommended therefore that government should provide additional funding to equip ICT laboratories in schools for effective takeoff of deployment radio teaching aid and electronic learning.
\end{abstract}

Keywords: Radio, teaching and learning, Secondary School, Owerri Education Zone 1 Imo State, ICTs

\section{Introduction}

Education has remained an integral tool of modernization and civil rule for governments at different levels in Nigeria. They continue to effect reform measures, especially, in response to globalization and the penchant to deploy channels and aids that improve access to quality and efficient education for the citizenries. Such reforms have made way for the deployment of Information Communication Technologies (ICTs) to facilitate and reinforce teaching and learning for the citizenries. By implication, achieving quality education, entails deploying efficient channels that ensure that the planned knowledge and skills are delivered to the target learners to influence the right decision, cognition, psychomotor, affection and behaviours. Thus, the message must be packaged in the right language and delivered through channels that are accessible to the target audience. Thereby

Corresponding Author: Mgbam, A.F., Secondary Education Management Board, Ministry of Education Imo State, Nigeria. E-mail: mimifrancez@yahoo.com 
sufficing the assertion that channel is a critical determinant in delivering quality education to a mass audience of learners.

Therefore, through the use of radio transmission channel for teaching and learning the earlier barriers of education due to spatial constraints are substantially removed. This fact was demonstrated when Marconi first transmitted messages in 1895 through the air by electronic impulses using wireless system (Okoroma et al., 2015). A Radio broadcast can be transmitted in real time for direct consumption or recorded and stored for onward use as audio disk or online content. Radio broadcast from the period of its advent till date, it has been a powerful and cost-effective means of creating awareness, stimulating interest, reinforcing spoken words, transferring knowledge and skills, changing behaviour, disaster alert, among others.

The low cost and reliability in all climates of miniature transistor radios makes it suitable at all times and in all place suitable for educational purpose. The flexibility of editing its contents and language into desired dialect and contents makes it effective in addressing context oriented learning situation. Iwu and Ezeako (2010) noted that it enables a mass audience of learners scattered across different locations to join, thereby removing the earlier barrier of face-to-face teaching situation. Today, emerging global phenomena like globalization, climate change, Covid-9 pandemic are reinforcing the need to optimize the use of radio as a teaching aid in Nigeria education system.

The latter informs why many secondary school teachers and schools in Imo State are joining their counterparts across the country to innovate strategic learning and mentorship classes on radio. Precisely, at different radio stations in Imo State broadcast live learning and mentorship sessions from secondary schools, enterprise institution, vocational centres in the State. Through this platform they stimulate learners' interest, sensitize the people, reinforce lessons, deliver knowledge to target audience at the comfort of their homes, workplaces, indoor or outdoor locations (Okoye, 2008). With the advancement in digital technologies the production and transmission of radio contents for educational purpose has improved substantially.

However, regardless of the huge potentials radio its use as a tool for delivering teaching and learning in secondary schools in Imo State the one-way nature of radio communication channel deprives the learning situation the usual student-teacher interactivity for effective knowledge transfer and feedback. In some cases the lessons broadcasted are technically distorted, thereby, undermining the credibility of the message and the messenger. Credibility according to Nwosu (2005) creates believability and vice versa. The dearth of secondary school teachers in the area who are technically skilled (lesson articulation, audio editing, audio effects) in producing radio contents for educational purposes is another contributory factor undermining the credibility of many radio broadcast lessons. Hence, understudying both sides of the divide, that is, the potentials and limitations of using radio in teaching is key in underscoring more efficient ways of deploying radio channel in secondary schools for effective learning, especially in this age of virtual communication.

\section{Objective of the study}

The study assessed the effects of radio communication channel on teaching at Secondary School level in Owerri Education Zone 1 of Imo State, Nigeria. The specific objectives include to:

i. ascertain ways radio is been utilized in teaching and learning at Secondary school level;

ii. assess the benefits in the use of radio for teaching and learning at Secondary school level;

iii. determine factors hindering effective use of radio for education development in Secondary Schools.

\section{Methodology}

The study was carried out in Owerri Education Zone 1 of Imo State of Nigeria. Imo State is located in the South Eastern zone of Nigeria and lies between latitudes $4^{0} 45^{\prime} \mathrm{N}$ and $7^{0} 15^{\prime} \mathrm{N}$ and longitude $6^{0} 50^{\prime} \mathrm{E}$ with a land area of 5,530 $\mathrm{Km}^{2}$ (National Population Commission, NPC, 2010). It is bordered by Abia State on the East, by River Niger and Delta State on the West, by Anambra State to the North and Rivers State to the South. The education structure of the State is delineated into Okigwe zone I, Okigwe zone II, Orlu zone I, Orlu zone II, Owerri zone I and Owerri zone II. Owerri zone I comprises of 5 Local Government Areas (LGAs), namely: Ikeduru, Mabitoli, Owerri Municipal, Owerri North and Owerri West. The choice of the zone is sequel to its relatively higher population of schools and students in the State. Secondary school teachers constitute the population of the study. 
Multistage sampling procedure was used in selecting the sample. First, one secondary school was purposively selected from each of the 5 LGAs in Owerri zone 1 based on the availability of audiovisual aids in the school. In the second stage, $50 \%$ of the teachers in each of the 5 selected schools were randomly selected to give a total sample size of 130 respondents. The sample frame was drawn from staff records provided by Imo State Secondary Education Management Board (SEMB). Table 1 below presents the summary of the sampling:

Table 1: Summary of Respondents' Proportionate (50\%) Sampling

\begin{tabular}{clcc}
\hline No. & Schools selected & $\begin{array}{c}\text { Total number of } \\
\text { teachers }\end{array}$ & $\begin{array}{c}\text { Number of } \\
\text { teachers sampled }\end{array}$ \\
\hline $\mathbf{1}$ & Boys' Model Secondary School World Bank & 60 & 20 \\
$\mathbf{2}$ & Girls Secondary School Akwakuma & 58 & 19 \\
$\mathbf{3}$ & Ubomiri Comprehensive Secondary School Mbaitoli & 46 & 13 \\
$\mathbf{4}$ & Comprehensive Secondary School Avu & 50 & 15 \\
$\mathbf{5}$ & Atta Boys' Secondary School & 45 & 13 \\
\hline
\end{tabular}

The study used primary data obtained from field survey using structured questionnaire. To achieve the study objectives, 4-point Likert type scale of Strong Agree $=4$, Agree $=3$, Disagree $=2$, Strongly Disagree $=1$ was used to capture scaling items measuring the ways radio is been utilized in teaching and learning; benefits in the use of radio for teaching and learning and factors hindering effective use of radio for education development in Secondary Schools in the study area. Mean score analysis was used in analyzing the data collected. The mean of the responses was obtained by adding the values of the scale and dividing by the number of scales to derive the discriminating index, while the discriminating index was set at a mean score of $\bar{X}>2.5$ for "accepted" and $\bar{X}<2.5$ for "not accepted".

\section{Result and Discussion}

\subsection{Utilization of radio for teaching at Secondary School level}

Table 2 is a mean distribution of teachers on ways of using radio for teaching at Secondary School Level. Using a discriminating of $\bar{X}>2.5$ (Accept); $\bar{X}<2.5$ (Reject), the result indicated that, the sampled teachers acknowledged that radio is used mostly for teaching and learning in distance learning programme $(\bar{X}=2.6)$.Also, radio programmes are used in creating awareness of topical issues among their students $(\bar{X}=2.7)$. On the other hand, the opinion that radio is used in teaching and learning outside their classroom as well as for academic work in the school in their school $(\bar{X}=$ 2.4) was rejected by the teachers. They also declined the views that Radio is used mostly for teaching and learning in their school's distance learning programme $(\bar{X}=2.3)$; prerecorded radio programmes are usually used in teaching their students with special needs $(\bar{X}=2.3)$; and that radio programmes are used in teaching subjects that require more of spoken words in their school $(\bar{X}=2.1)$. The average mean score of 1.6 which falls below the discriminating index of 2.5 shows that radio by the views of the teachers is not utilized for teaching at secondary level in Imo State. The average standard deviation value of 0.4 further revealed that the teachers were unanimous in their opinions regarding the use of radio for teaching in the study area. This result negates the earlier findings of several researchers regarding the use of radio for teaching. Such as studies by Syed, 2012; Okon and Okon (2013) which see instructional radio broadcast as intended to provide systematic instructional audio programme recorded and used in school in form of audio tapes, online audio downloads, audio books, audio folklore song, etc. As to why poor use of radio for teaching subsists, Uyouko et al., (2014) cited the high cost of producing and distributing radio message as a limiting factor discouraging the use of radio for teaching. They noted that ICTs available to Nigerian teachers often include cheap channels like adding machines, social media, projectors, megaphone. It is therefore believed that with the ongoing revolution in radio broadcasting that has birthed several institution-based radio stations across Nigeria will over time remove all technical and financial barriers limiting the use of radio for teaching at secondary school level. 
Table 2: Mean responses of teachers on the utilization of radio for teaching at Secondary School Level

\begin{tabular}{rlcccc}
\hline S/n & Ways of Using Radio for teaching & $\begin{array}{c}\text { Response } \\
\text { sum }\end{array}$ & Mean & $\begin{array}{c}\text { Standard } \\
\text { Deviation }\end{array}$ & Decision \\
\hline i. & $\begin{array}{l}\text { Radio is used in teaching and learning outside } \\
\text { our classroom }\end{array}$ & 314 & 2.4 & 0.3 & Reject \\
\hline ii. & $\begin{array}{l}\text { Radio is used by teachers and students for } \\
\text { academic work in our school }\end{array}$ & 318 & 2.4 & 0.4 & Reject \\
\hline iii. & $\begin{array}{l}\text { Radio is used mostly for teaching and learning } \\
\text { in our school's distance learning programme }\end{array}$ & 310 & 2.3 & 0.6 & Reject \\
\hline iv. $\quad \begin{array}{l}\text { Teachers use prerecorded radio programme in } \\
\text { school at convenient times }\end{array}$ & 338 & $2.6^{*}$ & 0.6 & Accept \\
\hline $\begin{array}{l}\text { Prerecorded radio programme are usually } \\
\text { used in teaching students with special needs in } \\
\text { our school }\end{array}$ & 310 & 2.3 & 0.3 & Reject \\
\hline vi. $\quad \begin{array}{l}\text { Radio programmes are used in creating } \\
\text { awareness of topical issues among our } \\
\text { students }\end{array}$ & 341 & $2.7 *$ & 0.4 & Accept \\
\hline $\begin{array}{l}\text { Radio programmes are used in teaching } \\
\text { subjects that require more of spoken words, } \\
\text { such as music }\end{array}$ & 290 & 2.1 & 0.4 & Reject \\
\hline & Average Mean Score & $\mathbf{1 . 6}$ & $\mathbf{0 . 4}$ & Reject \\
\hline Source: Field survey data (2016) & & & &
\end{tabular}

\subsection{Benefits of using radio for teaching at Secondary School level}

Table 3 is a mean distribution of teachers according to benefits of using radio for teaching at Secondary School Level. From the result, the teachers perceived radio beneficial in stimulating and holding students' interest in learning $(\bar{X}=3.1)$; reaching out to a large number of students at once while teaching $(\bar{X}=2.9)$; eliciting students' active participation when radio is used $(\bar{X}=2.9)$; creating effective communication amongst students and teachers $(\bar{X}=2.9)$. While, the teachers rejected the view that radio programme is cheap to design and used $(\bar{X}=2.0)$. Though the potentials of radio in enhancing teaching and learning are well known, however, the average mean score of 2.3 from the result indicated that the use of radio for teaching at Secondary School level in the study area was not significantly perceived beneficial by the teachers.

Table 3: Mean responses of teachers on the benefits of using radio for teaching at Secondary School Level

\begin{tabular}{clcccc}
\hline S/n & Benefits of Using Radio for teaching & $\begin{array}{l}\text { Response } \\
\text { sum }\end{array}$ & Mean & $\begin{array}{l}\text { Standard } \\
\text { Deviation }\end{array}$ & Decision \\
\hline 1. & Radio programme is cheap to design and used & 271 & 2.0 & 1.0 & Reject \\
\hline 2. & $\begin{array}{l}\text { While teaching, radio reaches out to a large number } \\
\text { of students at once }\end{array}$ & 236 & 2.9 & 0.9 & Accept \\
\hline 3. & Students participate actively when radio is used & 382 & 2.9 & 0.6 & Accept \\
\hline 4. & $\begin{array}{l}\text { Radio stimulates and holds students' interest in } \\
\text { learning }\end{array}$ & 409 & 3.1 & 0.4 & Accept \\
\hline 5. & $\begin{array}{l}\text { Radio enables fast and slow learners to learn at a } \\
\text { higher pace }\end{array}$ & 372 & 2,8 & 0.1 & Accept \\
\hline 6. & $\begin{array}{l}\text { Radio creates effective communication amongst } \\
\text { students and teachers }\end{array}$ & 382 & 2.9 & 0.3 & Accept \\
\hline & Average Mean & & $\mathbf{2 . 3}$ & $\mathbf{0 . 6}$ & Reject \\
\hline Source: Field survey data (2016) & $\bar{X}>2.5$ (Accept); $\bar{X}<2.5$ (Reject) &
\end{tabular}

The slightly high standard deviation value of 0.6 further showed that the teachers had divided opinion as to whether radio was beneficial or not for teaching at secondary level. This result undermines the assertions of Bamidele (2007) which hyped radio message as a powerful simulation for imaginative reasoning. According to him, "radio gives a chance for its audience to use their imagination to draw the picture of the events in the mind through radio a 'blind medium', coupled 
with its capability to stimulate listeners imagination and attention". The implication of this is that failure to utilize radio in teaching and learning such as witnessed in the study area is capable of undermining students' ability to develop imaginative capabilities. That is to say, producing secondary school students with imaginative abilities is key in realizing a generation of innovators that can keep pace with their counterparts across the world. Meanwhile, as to why some teachers may not see the use of radio for teaching beneficial, Okoroma et al., (2015) explained that even where radio channel is available, lack of technical abilities to script or produce a radio programme that will be fed to the channel hinder the use of radio for such purpose, thereby undermining the derivable benefits. In other words, beyond providing the radio channel, teachers should also be availed the technical abilities to use the radio.

\subsection{Factors constraining effective use of radio}

Table 4 is a mean responses of teachers by factors constraining the use of radio for teaching at Secondary School Level. The result revealed that inadequate funding of radio resources $(\bar{X}=3.2)$; limited time allocated for radio programme $(\bar{X}=3.0)$; education planners give little attention in the use of radio $(\bar{X}=3.2)$; lack of educational resource centre in schools $(\bar{X}=3.2)$; and lack of incentives for staff to motivate their use of radio in class $(\bar{X}=2.7)$ constrain the use of radio for teaching at Secondary School level. On the other hand, the fact that radio facilities are not adequately supplied by the necessary agency $(\bar{X}=2.3)$ and also that radio programme do not suit school time table $(\bar{X}=2.3)$ were not considered as significant constraint to the use of radio for teaching at Secondary School level in the study area. The average mean score of 2.8 indicated that the understudied items constituted significant constraints to the use of radio for teaching. The 0.6 standard deviation value of the teachers' opinions was slightly high implying that they were of divergent views regarding what constraints the use of radio and what does not in the area. This result corroborates the finding of Syed (2012) which identified inadequate funding, high cost of using radio broadcast, technical deficiency of teachers in producing instructional radio contents as well as using radio for teaching. Okon and Okon (2013) added that lack of information resource centre in schools and the absence of such consciousness on the part of education planners significantly undermine the use of the broadcast media for teaching. Therefore, efforts to improve the use of radio for teaching should begin with addressing the underlining constraints. Such efforts will be more effective if approached in a location specific manner considering the peculiarities of schools and their locations.

Table 4: Mean responses of teachers by factors constraining effective use of radio for teaching at secondary school level

\begin{tabular}{|c|c|c|c|c|c|}
\hline $\mathbf{S} / \mathbf{n}$ & Constraints to the use of Radio & Response sum & Mean & SD & Decision \\
\hline 1. & $\begin{array}{l}\text { Radio facilities are not adequately supplied by the } \\
\text { necessary agency }\end{array}$ & 305 & 2.3 & 1.3 & Reject \\
\hline 2. & There's inadequate funding of radio resources & 428 & 3.2 & 0.2 & Accept \\
\hline 3. & $\begin{array}{l}\text { There are always limited time allocated for radio } \\
\text { programme }\end{array}$ & 390 & 3.0 & 0.5 & Accept \\
\hline 4. & $\begin{array}{l}\text { There's lack of incentives for staff to motivate } \\
\text { their use of radio in class }\end{array}$ & 360 & 2.7 & 0.8 & Accept \\
\hline 5. & $\begin{array}{l}\text { Education planners give little attention in the use } \\
\text { of radio }\end{array}$ & 428 & 3.2 & 0.1 & Reject \\
\hline 6. & Lack of educational resource centre in schools & 426 & 3.2 & 0.5 & Accept \\
\hline \multirow[t]{2}{*}{1.} & Radio programme do not suit school time table & 293 & 2.3 & 1.1 & Reject \\
\hline & Average Mean & & 2.8 & 0.6 & Accept \\
\hline
\end{tabular}

\section{Conclusion and Recommendations}

The study concludes that radio is used mostly for teaching and learning in distance learning programme. Radio programmes are used by the teachers in creating awareness of topical issues among their students. Radio was perceived beneficial in stimulating and holding students' interest in learning, reaching out to a large number of students at once while teaching, eliciting students' active participation and creating effective communication amongst students and teachers. Inadequate 
funding of radio resources, limited time allocated for radio programme, limited attention in the use of radio, lack of educational resource centre in schools and lack of incentives for staff to motivate their use of radio in class constrain the use of radio for teaching at Secondary School level. It is therefore recommended that:

- Government should provide separate and additional funding to equip ICT laboratories in schools for effective takeoff of electronic learning.

- Educational financiers should dedicate more funds towards providing more broadcast time for educational programmes. This will enable more educational contents to get to listeners, thereby creating mass education.

- Teachers should be motivated to use radio programmes for teaching. Such as giving them bonus network subscription to enable them continue to use the media.

- More attention should be given to e-learning by curriculum planners to raise awareness as well as increase knowledge and skills about the use of radio for teaching.

- Information resource centres should be provided across schools to enhance access to information and communication.

- Periodic training should be given to Secondary teachers in order to enhance their technical abilities to create radio programmes for onward broadcasting. This will also enable them come to speed with trendy issues regarding the use of radio for the purpose of education.

\section{References}

Bamidele, B., 2007. The Coming into being of NTA Education. Journal of the NTA - Education Television Centre 4(2) 8-9.

Iwu, A. and R.C. Ezeako, 2010. The relevance of broadcasting in the tertiary institutions in Nigeria. Conference proceedings of Nigeria Association for Education Media and Technology (NAEMT), 2.

Lewis, B. and R. Smith, 2002. The development of an electronic education portfolio: An outline for medical education professional. Teaching and Learning in Medicine, 19(2):139-147.

National Population Commission, 2010. Population distribution by sex, states, L.G.As and senatorial districts, housing consus, priority tables vol. 111 NPC, Abuja, Nigeria. Retrieval 10/10/2014 from www.population.gov.ng/2006/national and state population and housing $/ \mathrm{htm}$.

Nwosu, I., 2005. Media development: abroad perspective. Nigeria, Enugu Cecta.

Okon, E.E. and F.I. Okon, 2013. ICT Utilization and Teaching - Learning in Business Education in Tertiary Institutions in Cross River State. Mediterranean Journal of Social Sciences. Published by MCSER-CEMAS-Sapienza University of Rome.

Okoroma, E.O., F.N. Nnadi, , F.C. Anaeto, J.A. Echetama, M.N. Uche-Nwachi and C.A. Anaeto, 2015. Utilization of "radio farmer" programme of Imo State Agricultural Development Programme by rural farmers in Imo State, Nigeria. Journal of Biology, Agriculture and Healthcare, 5(13): 2224-3208 Available at www.iiste.org.

Okoye, J.J., 2008. Dynamics of Radio and Television Production. A Multi-Dimension Approach. Enugu: Ebyboy Business World.

Syed, N., 2012. An Effective use of ICT for Education and Learning by Drawing on Worldwide Knowledge, Research, and Experience: ICT as a Change Agent for Education

Uyouko, A.U., S.L. Wong, and A.F. Ayub, 2014. ICT Access and the Nigerian Teacher: A Literature Review. Middle-East Journal of Scientific Research, 19 (Innovation Challenges in Multidisciplinary Research \& Practice): ISSN 1990-9233 